\title{
FAKTOR-FAKTOR YANG DIPERTIMBANGKAN DALAM KEPUTUSAN PEMBELIAN MINYAK GORENG BIMOLI PADA IBU RUMAH TANGGA DESA KEBONAGUNG KECAMATAN PURWOREJO KOTA PASURUAN
}

\author{
M. Bukhori \\ Dosen STIE Asia Malang \\ Tutik Ekasari \\ Alumni STIE Asia Malang
}

\begin{abstract}
Consumer behavior towards purchasing decisions is something that should be studied by marketers to know and understand how consumers make decisions, and the extent to which marketing stimuli can provide stimulation to the purchasing decision. So they can know what are the factors that influence consumer purchasing decisions. The purpose of this study was to determine the factors that are considered in the purchase decision ofcookingoil Bimoli housewives Kebonagung Village District Purworejo Pasuruan.

Population and sample in this study were housewives Kebonagung Village District Purworejo Town of Pasuruan who bought and used cooking oil Bimoli. The number of samples is determined using a quota sampling of 50 respondents, the sampling technique used purposive sampling. Methods of data collection using observation, interviews, and questionnaires. Analyzed using factor analysis to test the hypothesis.
\end{abstract}

The results showed that of the eight factors suspected to be considered in the purchase decision, there are five factors that influence purchasing decisions, namely: price factors, social factors, psychological factors, distribution factors, and personal factors. Keywords: Factor Prices, Social Factors, Psychological Factors, Distribution Factors, Personal Factors, Purchase Decision.

\section{ABSTRAKSI}

Perilaku konsumen terhadap keputusan pembelian merupakan sesuatu yang harus dipelajari oleh pemasar untuk mengetahui dan memahami cara konsumen dalam mengambil keputusan, dan sejauh mana marketing stimuli bisa memberikan rangsangan terhadap keputusan pembelian. Sehingga bisa diketahui apa saja yang faktor-faktor yang mempengaruhi konsumen dalam keputusan pembelian. Tujuan dari penelitian ini adalah untuk mengetahui faktor-faktor yang dipertimbangkan dalam keputusan pembelian minyak goreng Bimoli pada ibu rumah tangga Desa Kebonagung Kecamatan Purworejo Kota Pasuruan.

Populasi dan sampel dalam penelitian ini adalah ibu rumah tangga Desa Kebonagung Kecamatan Purworejo Kota pasuruan yang membeli dan menggunakan minyak goreng Bimoli. Jumlah sampel ditentukan menggunakan quota sampling sebanyak 50 responden, dengan teknik pengambilan sampel menggunakan purposive sampling. Metode pengumpulan data menggunakan observasi, wawancara, dan kuesioner. Dianalisis menggunakan analisis faktor dengan uji hipotesis.

Hasil penelitian menunjukkan bahwa dari 8 faktor yang diduga dipertimbangkan dalam keputusan pembelian, terdapat 5 faktor yang mempengaruhi keputusan pembelian, yaitu : faktor harga, faktor sosial, faktor psikologis, faktor distribusi, dan faktor pribadi. Kata Kunci : Faktor Harga, Faktor Sosial, Faktor Psikologis, Faktor Distribusi, Faktor Pribadi, Keputusan Pembelian.

\section{PENDAHULUAN}

Indonesia merupakan negara agraris yang kaya akan sumberdaya alam dan mempunyai ketersediaan lahan yang luas untuk menunjang kegiatan pertanian. Kegiatan pertanian yang ada di Indonesia menghasilkan bahan pokok makanan yang di konsumsi sehari-hari oleh sebagian besar masyarakat indonesia. Hasil-hasil pertanian yang ada terdiri atas tanaman pangan (padi, jagung, ketela pohon, ubi jalar, kedelai dan kacang tanah) dan tanaman perdagangan (teh, tebu, kopi, karet, kelapa sawit, kelapa, kina, cengkeh, kapas).
Kedua hasil pertanian tersebut bisa di olah untuk menjadi bahan makanan maupun minuman untuk memenuhi kebutuhan pangan masyarakat Indonesia (belajar.kemdikbud.go.id, 2008).

Dari sekian bany aknya hasil pertanian y ang ada di Indonesia, kelapa sawit merupakan salah satu hasil pertanian yang memberikan manfaat yang cukup besar dalam pemenuhan kebutuhan pokok masyarakat Indonesia. Kelapa sawit bisa dimanfaatkan untuk membuat minyak goreng, margarin, sabun, kosmetika, dan lain-lain. Minyak goreng merupakan salah satu bahan makanan yang banyak digunakan untuk kehidupan sehari-hari. Minyak goreng digunakan sebagai media menggoreng yang bertujuan untuk 
menjadikan makanan gurih dan renyah, meningkatkan cita rasa, perbaikan tekstur dan pembawa rasa.

Industri minyak goreng sawit di Indonesia menjadi dua, yaitu minyak goreng curah dan minyak goreng kemasan bermerek. Minyak goreng curah merupakan minyak goreng yang dijual ke pasar tanpa menggunakan merek dan label produk yang biasanya ditempatkan di dalam jerigen besar atau drum lalu dijual kepada konsumen secara eceran. Minyak goreng kemasan bermerek adalah minyak goreng yang ditawarkan ke pasar dengan menggunakan kemasan, merek, dan label produk.

Peralihan pola konsumsi masyarakat dari minyak goreng curah ke minyak goreng bermerek pun semakin besar. Minyak goreng yang dikemas dalam botol atau plastik dianggap lebih bersih dan higienis oleh masyarakat daripada minyak goreng yang dijual eceran oleh pedagang keliling yang ditempatkan di dalam jerigen dan drum. Hal ini semakin membuka lebar peluang pasar bagi industri minyak goreng bermerek. Selain itu, minyak goreng merupakan bahan pokok kebutuhan sehari-hari sehingga hampir seluruh masyarakat Indonesia mengkonsumsinya.

Di Indonesia terdapat beberapa perusahaan yang mengolah kelapa sawit menjadi minyak goreng, salah satunya adalah Grup Indofood dengan merek dagang minyak goreng "Bimoli" di bawah bendera PT. Salim Ivomas Pratama Tbk. yang di produksi sejak tahun 1970-an dengan slogan "Kesempurnaan Minyak Goreng”. Minyak goreng Bimoli berusaha menyajikan kualitas minyak terbaik dengan melakukan proses pengolahan enam tahap, mulai dari penghilangan getah, penjernihan warna minyak, penghilangan asam lemak bebas, pemurnian aroma, pembentukan fraksi padat sampai pemisahan fraksi padat dan minyak. Termasuk juga mempunyai kandungan Omega 9 yang berfungsi menjaga kadar normal kolesterol. Minyak goreng Bimoli terus menjaga kualitas produknya agar mendapat kepercayaan dari masyarakat akan mutu dan kualitasnya. Minyak goreng Bimoli pernah meraih Platinum Best Brand Award untuk kategori minyak goreng. Penghargaan itu diberikan berdasarkan survey yang dilakukan oleh Majalah SWA Sembada dan MARSMarketing Research dengan melibatkan 4.100 responden di lima kota besar di Indonesia (www.tempo.com, 2011).

Selain itu, minyak goreng Bimoli juga menjadi Top Brand nomor 1 di kelas minyak goreng, berdasarkan survey yang melibatkan delapan kota besar di Indonesia yang antara lain adalah kota Jakarta, Bandung, Semarang, Surabaya, Makassar, Medan, Pekanbaru dan Balikpapan, seperti tertuang pada tabel berikut

Berdasarkan tabel di atas, bisa terlihat bahwa minyak goreng Bimoli menduduki posisi pertama dan menjadi Top Brand untuk kelas minyak goreng dengan prosentase sebesar 44,7\%, disusul dengan Tropical dan Sania di posisi kedua dan ketiga dengan prosentase sebesar $15,1 \%$ dan $12,9 \%$. Top Brand yang telah diraih di hitung berdasarkan banyaknya pembelian yang dilakukan oleh konsumen terhadap masing-masing merek minyak goreng. Melihat selisih angka prosentase pada masing-masing merek minyak goreng, bisa dipastikan bahwa didalamnya terdapat persaingan yang ketat dari perusahaan dalam menjual produknya, baik persaingan kualitas produk, harga, promosi serta distribusinya. Persaingan harga masing-masing minyak goreng kemasan bisa dilihat dalam berikut :

Berdasarkan tabel diatas bisa di lihat bahwa harga minyak goreng Bimoli cenderung lebih mahal dari minyak goreng kemasan bermerek lainnya, yaitu sebesar Rp. 14.000 perliternya. Setiap minyak goreng kemasan menawarkan harga dan kualitas yang hampir sama. Ditambah lagi, komsumen minyak goreng bukanlah tipe konsumen yang loyal untuk produk ini. Pada kasus minyak goreng, konsumen akan memilih membeli minyak goreng bukan karena kandungannya namun lebih pada hal-hal yang bersifat direct behavior, misalnya harga promo, bundling, dll. Hal ini membuat persaingan bisnis antar minyak goreng kemasan bermerek semakin ketat (www.topbrandaward.com, 2012). Meskipun harga minyak goreng Bimoli lebih mahal dari minyak goreng kemasan bermerek yang lain, minyak goreng Bimoli tetap memiliki konsumennya sendiri dalam lapisan masyarakat. Sehingga meskipun harganya lebih mahal, minyak goreng Bimoli tetap di minati dan dibeli oleh konsumen.

Pembelian yang dilakukan konsumen terhadap minyak goreng Bimoli tidak lepas dari keputusan konsumen itu sendiri dalam menentukan produk apa yang akan dibeli.Keputusan

pembelian oleh konsumen di pengaruhi oleh banyak hal, yang salah satunya adalah perilaku konsumen. Menurut Suwarman (2002:25), Perilaku konsumen adalah tindakan yang langsung terlibat dalam mendapatkan, mengkonsumsi dan menghabiskan produk dan jasa, termasuk proses keputusan yang mendahului dan mengikuti tindakan ini. Dalam pengambilan keputusan keputusan pembelian minyak goreng Bimoli terdapat keadaan yang mendasari atau mempengaruhi terjadinya suatu keputusan pembelian. Keadaan yang mendasari inilah yang disebut dengan faktor. Menurut Kotler (2005 : 202 ) ada 4 faktor yang mempengaruhi perilaku konsumen terhadap keputusan pembelian, yaitu : faktor budaya (budaya, sub- 
budaya, dan kelas sosial), faktor sosial (kelompok acuan, keluarga, peran dan status), faktor individu (usia dan tahap siklus hidup, pekerjaan dan lingkungan ekonomi, gaya hidup, kepribadian dan konsep diri), dan faktor psikologis (motivasi, persepsi, pembelajaran, keyakinan dan sikap). Selain itu, terdapat marketing stimuli sebagai rangsangan pemasaran bagi konsumen untuk melakukan pembelian yang terdiri dari produk, harga, distribusi dan promosi.

Perilaku konsumen terhadap keputusan pembelian minyak goreng Bimoli merupakan sesuatu yang seharusnya dipelajari oleh pemasar untuk mengetahui dan memahami cara konsumen dalam mengambil keputusan, dan seberapa besar marketing stimuli bisa memberikan rangsangan terhadap keputusan pembelian oleh konsumen. Dan hal tersebut menuntut peneliti untuk meneliti apa yang mempengaruhi konsumen dalam membeli minyak goreng Bimoli.

Pemahaman tentang konsumen dalam pembelian minyak goreng Bimoli dapat dilakukan dengan mengadakan penelitian dengan mengukur faktor-faktor yang dipertimbangkan oleh konsumen dalam keputusan pembelian minyak goreng Bimoli. Sehingga dalam penelitian ini peneliti mengangkat pembahasan penelitian tentang faktor-faktor yang dipertimbangkan dalam keputusan pembelian minyak goreng Bimoli, dengan lokasi penelitian dilaksanakan di Desa Kebonagung, Kecamatan Purworejo, Kota Pasuruan dengan pertimbangan minyak goreng Bimoli banyak dijual baik di toko, swalayan, minimarket, supermarket maupun retail lain yang ada dalam daerah tersebut.

\section{KAJIAN PUSTAKA}

Menurut Kotler (2007 : 6) "Pemasaran adalah suatu fungsi organisasi dan seperangkat proses untuk menciptakan, mengkomunikasikan, dan menyerahkan nilai kepada pelanggan dan mengelola hubungan pelanggan dengan cara yang menguntungkan organisasi dan para pemilik sahamnya

\section{Perilaku Kons umen}

Perilaku konsumen menurut Kotler (2007:213) adalah "studi tentang cara individu, kelompok, dan organisasi menyeleksi, membeli, menggunakan, dan mendisposisikan barang, jasa, gagasan atau pengalaman untuk memuaskan kebutuhan dan keinginan mereka. Studi konsumen memberikan petunjuk untuk memperbaiki dan memperkenalkan produk atau jasa, menetapkan harga, merencanakan saluran, menyusun pesan, dan mengembangkan kegiatan pemasaran lain. oleh karena itulah memahami perilaku konsumen dan mengenal kebutuhan dan keinginan mereka tidak sederhana.

Berikut ini adalah sebuah bagan yang menggambarkan model perilaku konsumen yang menjelaskan proses terjadinya pengambilan keputusan oleh konsumen untuk membeli.

\section{Model perilaku konsumen menurut Kotler}

Sumber : Philip Kotler (2007-226)

Model ini disebut juga dengan Model of Buyer Behavior, menjelaskan proses terjadinya pengambilan keputusan oleh konsumen untuk melakukan pembelian. Model ini di awali dengan rangsangan pemasaran (marketing stimuli) yang terdiri dari: a. Produk (Product) b. Harga (Price) c. Distribusi (Place) d. Promosi (Promotion)

Rangsangan marketing tersebut dapat di lengkapi dengan adanya rangsangan-rangsangan lain, seperti :

1. Ekonomi (Economic) 2. Teknologi (Technology) 3. Politik dan hukum (Political) 4. Budaya (Cultural)

\section{Faktor-Faktor Yang Mempengaruhi Perilaku Kons umen}

Kotler (2005:202) menyatakan perilaku pembelian konsumen dipengaruhi oleh faktorfaktor budaya, sosial, pribadi, dan psikologis, yang dijelaskan seperti berikut :

a. Faktor Budaya menurut Kotler (2005:203) terbagi menjadi 3 yaitu : Budaya menurut, merupakan penentu keinginan dan perilaku yang paling dasar. Meliputi berbagai nilai, persepsi, preferensi, perilaku dan kebiasaan. Sub-budaya, masingmasing dari budaya terdiri dari sejumlah subbudaya yang lebih kecil lagi dan memiliki sosialisasi khusus bagi para anggotanya. Subbudaya mencakup kebangsaan, agama, kelompok ras, dan wilayah geografis.

Kelas Sosial, merupakan pembagian masyarakat yang relative homogen dan permanen, yang tersusun secara hierarkis dan para anggotanya menganut nilai, minat dan perilaku yang serupa.

\section{b.Faktor Sosial menurut Kotler (2005:206),} merupakan faktor yang timbul dari lingkungan sosial konsumen. Faktor ini meliputi :

1. Kelompok Acuan. Kelompok acuan 
seseorang terdiri dari semua kelompok yang memiliki pengaruh langsung (tatap muka) atau tidak langsung terhadap sikap atau perilaku seseorang. Kelompok yang memiliki pengaruh langsung terhadap seseorang dinamakan kelompok kanggotaan. Kelompok keanggotaan dibagi menjadi dua, yaitu kelompok primer (keluarga, teman, tetangga, dan rekan kerja yang berinteraksi dengan seseorang secara terus-menerus dan informal) dan kelompok sekunder (kelompok keagamaan, profesi, dan asosiasi perdagangan, yang cenderung lebih formal dan membutuhkan interaksi yang tidak begitu rutin).

2. Keluarga, merupakan organisasi pembelian konsumen yang paling penting dalam masyarakat, dan para anggota keluarga menjadi kelompok acuan primer yang paling berpengaruh.

3.Peran dan Status. Peran meliputi kegiatan yang diharapkan akan dilakukan oleh seseorang, sedangkan status merupakan kedudukan seseorang dalam lingkungan.

c. Faktor Pribadi menurut Kotler (2005:210), adalah faktor yang berasal dari pengaruh karakteristik pribadi seorang konsumen, dan karakteristik ters ebut meliputi :

1. Usia dan Tahap Siklus Hidup. Perilaku konsumen juga dapat dipengaruhi oleh usia, karena usia mempengaruhi kebutuhan seseorang. Semakin tua usia maka kebutuhan akan semakin besar. Sedangkan tahap siklus hidup merupakan pembagian dari periode hidup konsumen.

2.Pekerjaan dan Lingkungan Ekonomi. Pekerjaan mempengaruhi pola kebutuhan, semakin baik jenis pekerjaan konsumen, maka tingkat kebutuhan dan keinginnya akan semakin besar. Lingkungan ekonomi juga berpengaruh terhadap perilaku konsumen, hal ini berkaitan dengan penghasilan, semakin besar penghasilan maka akan semakin besar pula kebutuhan.

3.Gaya Hidup, merupakan pola hidup seseorang di dunia yang terungkap pada aktivitas, minat dan opininya. Gaya hidup juga menggambarkan keseluruhan diri seseorang yang berinteraksi dengan lingkungannya.

4.Kepribadian dan Konsep Diri. Kepribadian adalah ciri bawaan psikologi manusia (human psychological traits) yang terbedakan dan menghasilkan tanggapan relatif konsisten dan bertahan lama terhadap lingkungannya. Sedangkan konsep diri merupakan pandangan tentang diri seseorang, baik pandangan terhadap diri sendiri maupun pandangan dari orang lain.

d. Faktor Psikologis menurut Kotler (2005:215), merupakan faktor yang di pengaruhi oleh bagian psikologis seorang manusia yang meliputi : a.Motivasi, merupakan dorongan dari diri sendiri untuk melakukan aktivitas. Dalam hal ini adalah pembelian.

b.Persepsi, merupakan proses yang digunakan oleh seorang individu untuk memilih, mengorganisasi, menginterprestasi masukan informasi guna menciptakan gambaran dunia yang memiliki arti.

c.Pembelajaran, meliputi perubahan perilaku seseorang yang timbul dari pengalaman yang sebagian besar adalah hasil dari belajar.

d.Keyakinan dan Sikap. Keyakinan merupakan adalah gambaran pemikiran yang di anut seseorang tentang gambaran sesuatu. Sedangkap sikap adalah evaluasi, perasaan emosional dan kecenderungan tindakan yang menguntungkan atau merugikan dan bertahan lama dari seseorang terhadap suatu obyek atau gagasan.

\section{Tahap-Tahap Keputusan Pembelian}

Menurut Kotler (2005:224), untuk sampai pada tahap pembelian terdapat langkahlangkah dalam proses pembelian dengan suatu tahapan. Proses pengambilan keputusan meliputi serangkaian tahapan meliputi : identifikasi kebutuhan, pencarian alternative, evaluasi alternative, perilaku pembelian, dan perilaku purna beli.

\section{METODE PENELITIAN}

Lokasi Penelitian

Lokasi penelitian dilakukan di Desa Kebonagung, Kecamatan Purworejo, Kota Pasuruan.

\section{Jenis Penelitian}

Jenis penelitian yang digunakan adalah explanatory research, menurut Singarimbun (2006:5) menjelaskan bahwa explanatory research adalah penelitian yang menjelaskan hubungan kausah antara variabel-variabel penelitian melalui uji hipotesis yang telah dirumuskan sebelumnya. Dalam penelitian ini explanatory research digunakan untuk mengetahui adanya hubungan faktor produk, harga, promosi, distribusi, budaya, pribadi, sosial, dan psikologis yang dipertimbangkan dalam keputusan pembelian minyak goreng Bimoli pada ibu rumah tangga Desa Kebonagung Kecamatan Purworejo Kota Pasuruan. 


\section{Populasi}

Populasi adalah objek atau subjek yang berada pada suatu wilayah dan memenuhi syarat-syarat tertentu berkaitan dengan masalah penelitian (Riduwan, 2005:54). populasi dalam penelitian ini adalah ibu rumah tangga Desa Kebonagung, Kecamatan Purworejo, Kota Pasuruan yang membeli dan menggunakan minyak goreng Bimoli.

\section{Sampel}

Sampel adalah bagian dari populasi. Menurut Hadi (2000:121), sampel adalah sebagian dari populasi atau sejumlah penduduk yang jumlahnya kurang dari populasi. Oleh karena populasi pembeli minyak goreng Bimoli dalam penelitian ini tidak diketahui jumlah pastinya, maka peneliti menggunakan quota sampling dalam penentuan jumlah sampelnya.

Menurut Sugiyono (2001:60), quota sampling merupakan teknik untuk menentukan sampek dari populasi yang mempunyai ciri-ciri tertentu sampai jumlah (kuota) yang diinginkan. Sehingga sampel dalam penelitian ini telah ditentukan sebanyak 50 responden. Sedangkan untuk teknik penentuan sampelnya menggunakan purposive sampling. Menurut Sugiyono (2001:61) purposive sampling adalah teknik penentuan sampel dengan pertimbangan tertentu. Adapun kriteria sampel dalam penelitian ini adalah ibu rumah tangga Desa Kebonagung yang membeli dan menggunakan minyak goreng Bimoli selama 3 bulan terakhir dari waktu diadakannya penelitian ini.

\section{Jenis Data}

Jenis data yang digunakan dalam penelitian ini adalah jenis data kuantitatif yang berasal dari data kualitatif (menyebarkan angket ke responden) yang dikuantitatifkan agar dapat diproses menggunakan statistik. Menurut Sugiyono (2011:8), kuantitatif adalah metode penelitian yang berlandaskan filsafat positivisme, digunakan untuk meneliti pada populasi dan sample tertentu, pengumpulan data menggunakan instrumen penelitian, analisis data

bersifat kuantitatif, penggunaan statistik dengan tujuan untuk menguji hipotesis yang ditetapkan.

\section{Sumber Data}

\section{Data Primer}

1.Data primer adalah data yang diperoleh langsung dari lapangan termasuk laboratorium, Nasution (2003:143). Tehnik yang digunakan adalah dengan menggunakan metode wawancara dan kuesioner.

2. Data Sekunder Data Sekunder, merupakan data yang sudah tersedia sehingga peneliti tinggal mencari dan mengumpulkan data tersebut (Jonathan Sarwono, 2006:11). Penelitian ini menggunakan data sekunder yang diperoleh dari jurnal, majalah, buku, serta penelitian terdahulu yang membuat informasi atau data-data yang berkaitan dengan penelitian berupa bukti, catatan atau laporan historis yang telah tersusun dalam arsip baik yang dipublikasikan maupun tidak dipublikasikan.

\section{Metode dan Pengumpulan Data \\ 1. Observasi \\ Observasi sebagai tehnik pengumpulan data mempunyai ciri yang spesifik bila dibandingkan dengan tehnik yang lain, yaitu wawancara dan kuesioner. Menurut Sutrisno (dalam Sugiyono, 2009 : 203) mengemukakan bahwa, observasi merupakan suatu proses yang kompleks, suatu proses yang ters usun dari berbagai proses biologis dan psikologis. Dua di antara yang terpenting adalah proses-proses pengamatan dan ingatan.}

\section{Wawancara}

Wawancara adalah cara pengumpulan data dengan jalan tanya jawab sepihak yang

dikerjakan secara sistematik dan berlandaskan kepada tujuan penelitian untuk memperoleh informasi langsung dari sumbernya (Arikunto :2006). Dalam penelitian ini wawancara di lakukan kepada beberapa responden dengan pertanyaan terbuka terkait keputusan pembelian minyak goreng Bimoli.

\section{Kuesioner}

Kuesioner merupakan teknik pengumpulan data yang dilakukan dengan cara

memberi seperangkat pertanyaan atau pernyataan tertulis kepada responden untuk

dijawabnya, (Sugiyono, 2011:199). Dalam mengetahui pendapat responden dalam menjawab pertanyaan-pertanyaan yang sudah diajukan, maka digunakanlah kuesioner sebagai alat pengumpulan data yang merupakan sejumlah pertanyaan tertulis yang berguna untuk memperoleh informasi 
dari responden.

4. Dokumentasi

Dokumentasi adalah mempelajari dasar - dasar teori maupun data praktis dari perpustakaan maupun internet sehubungan dengan judul atau pokok bahasan yang diteliti. Dalam melakukan dokumentasi, penulis menggunakan buku - buku, artikel dari perpustakaan maupun data - data dari internet dan media tulis atau majalah lainnya yang berhubungan dengan penelitian ini.

\section{DEFINISI OPERASIONAL VARIABEL}

1. Faktor-faktor yang dipertimbangkan dalam keputusan pembelian minyak goreng Bimoli pada ibu rumah tangga Desa Kebonagung Kecamatan Purworejo Kota Pasuruan merupakan variabel tunggal dalam penelitian. Dimana terdapat delapan subvariabel yang dipertimbangkan konsumen dalam keputusan pembelian yang antara lain faktor produk, harga, promosi, distribusi, budaya, pribadi, sosial, dan psikologis.

2.Faktor Produk

Produk dalam penelitian ini adalah minyak goreng Bimoli, dimana konsumen bisa memberikan penilaian terhadap produk yang ditawarkan oleh perusahaan, seperti merek, kualitas, kemasan, dan label yang ada pada kemasan. Produk dalam penelitian ini menggunakan indikator sebagai berikut :

a. Merek b. Kualitas produk c. Kemasan dan varian kemasan d. Label pada kemasan 3.Faktor Harga

Harga merupakan merupakan sejumlah uang yang dibutuhkan atau dikeluarkan untuk memperoleh produk minyak goreng Bimoli. Harga minyak goreng Bimoli pada penelitian ini menggunakan indikator sebagai berikut :

a. Harga terjangkau b. Harga sesuai kualitas

c. Harga bersaing d. Harga sesuai manfaat

4. Faktor Promosi

Promosi merupakan komunikasi yang ditujukan perusahaan kepada konsumen yang bertujuan untuk membujuk konsumen agar membeli produk yang ditawarkan perusahaan, yaitu minyak goreng Bimoli. Indikator penelitian sebagai berikut:

a. Iklan minyak goreng Bimoli b. Promosi penjualan minyak Goreng Bimoli

5. Faktor Distribusi

Distribusi

merupakan kegiatan pemasaran minyak goreng Bimoli yang ditujukan untuk mempermudah penyampaian produk ke konsumen seperti lokasi, tempat penjualan, dan cakupan distribusi. Distribusi dalam penelitian ini menggunakan indikator berikut :

a. Kemudahan memperoleh minyak goreng

Bimoli b. Lokasi/tempat membeli minyak goreng

Bimoli

6. Faktor Budaya

Budaya merupakan kebiasaan dan pengalaman konsumen yang pernah mengkonsumsi minyak goreng Bimoli, dimana kebiasaaan dan pengalaman tersebut sebagai persepsi dan penentu keputusan pembelian. Budaya dalam penelitian ini menggunakan indikator sebagai berikut :

a. Kebiasaan b. Anjuran teman atau keluarga

7. Faktor Pribadi

Pribadi dalam keputusan pembelian minyak goreng Bimoli merupakan faktor yang di pengaruhi oleh usia, pekerjaan, keadaan ekonomi, dan gaya hidup. Pribadi dalam penelitian ini menggunakan indikator sebagai berikut : a. Usia b. Pekerjaan c. Keadaan ekonomi d. Gaya hidup

8. Faktor Sosial

Sosial merupakan keyakinan konsumen untuk mengikuti referensi, baik dari keluarga, rekan kerja, teman dekat, dan rekan komunitas untuk membeli minyak goreng Bimoli. Dalam penelitian ini sosial menggunakan indikator sebagai berikut: a. Keluarga b. Rekan kerja c. Teman dekat d. Rekan komunitas 9. Faktor Psikologis

Psikologis merupakan keputusan pembelian minyak goreng Bimoli oleh seorang konsumen yang dipengaruhi oleh motivasi, persepsi, pembelajaran, serta sikap dan keyakinan. Psikologis dari penelitian ini menggunakan indikator sebagai berikut: a. Motivasi b. Persepsi c. Pembelajaran d. Keyakinan

\section{Metode Analisis Data dan Uji Hipotesis Uji Validitas}

Hasil uji validitas terhadap 26 butir pertanyaan yang berasal dari 8 sub-variabel menghasilkan nilai rhitung lebih besar dari 0,354. Sehingga uji validitas untuk kuesioner penelitian adalah valid.

\section{Uji Reliabilitas}

Hasil uji reliabiltas terhadap 8 sub-variabel keseluruhan adalah lebih besar dari 0,6 sehingga seluruh butir pertanyaan telah reliabel.

\section{Analisis Faktor}

Faktor diukur dengan 8 Variabel dari hal-hal yang mempengaruhi Keputusan Pembelian.

\section{Hasil Analisis Faktor pertama untuk Variabel} X1

Berdasarkan tabel,diperoleh bahwa seluruh nilai 
MSA telah di atas 0,500 terkecuali Produk dan Budaya. Selain itu nilai loading factor keseluruhan variabel juga telah di atas 0.500, terkecuali Promosi. Sehingga selanjutnya analisis faktor dilakukan kembali dengan mengeksklusi variabel Produk, Budaya dan Promosi. Hasil analisis faktor selanjutnya dijabarkan dalam tabel berikut:

Hasil Analisis Faktor kedua untuk Variabel X1 Berdasarkan tabel, diperoleh bahwa seluruh nilai MSA telah di atas 0,500 sehingga dapat disimpulkan bahwa variabel pada Faktor Keputusan Pembelian dapat digunakan. Indeks KMO measure of sampling adequacy yang tinggi sebesar 0,833 menunjukkan telah tepatnya analis is faktor yang dihasilkan. Sedangkan untuk uji Bartlett, hipotesisnya adalah:

$\mathrm{H}_{1}=$ variabel-variabel tidak saling berkorelasi

dalam populasi(matriks korelasi populasi

merupakan matriks identitas) $\square=0,05$

Kriteria pengujian: Ha diterima jika angka Sig.

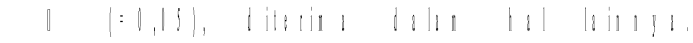
Terlihat pada tabel di atas angka Sig. sebesar 0,000 (jauh di bawah $\square=0,05$ ), sehingga $\mathrm{H}_{0}$ ditolak. Berarti syarat interdependensi antar variabel telah dipenuhi.

Dalam tabel juga bisa dilihat bahwa harga mempunyai nilai komunalitas sebesar 0,805, ini menunjukkan jika 80,5\% varian harga telah di jelaskan dalam faktor yang ada. Distribusi dengan nilai komunalitas sebesar 0,643 menunjukkan bahwa $64,3 \%$ varian distribusi telah dijelaskan dalam faktor yang ada. Pribadi dengan nilai komunalitas sebesar 0,618 menunjukkan bahwa 61,8\% varian pribadi telah dijelaskan dalam faktor yang ada. Sosial dengan nilai komunalitas sebesar 0.800 menunjukkan bahwa $80 \%$ varian sosial telah dijelaskan dalam faktor yang ada. Dan psikologis dengan nilai komunalitas sebesar 0,792 menunjukkan bahwa 79,2\% varian psikologis telah dijelaskan dalam faktor yang telah ada.

Setelah syarat interpendensi terpenuhi, maka analisis selanjutnya adalah ekstraksi faktor untuk melihat seberapa banyak faktor yang mungkin terbentuk dengan melihat tabel Total Variance Explained (Santoso, 2006:42).

Dari nilai Component berkisar antara 1-5

yang mewakili faktor-faktor yang mempengaruhi keputusan pembelian. Dengan penentuan nilai eigenvalues $>1$, maka varians dari faktor yang terbentuk diambil dari nilai total eigenvalues yang lebih dari 1 . Dari tabel tersebut juga bisa dilihat jika faktor yang terbentuk adalah 1 faktor dengan nilai total eigen values sebesar 3,659, dan nilai varians bisa dihitung dengan membagi nilai total eigenvalues dengan banyaknya component yang mewakili variabel dikali 100 persen. 3.659 : 5 x 100\% = 73,18\% Sehingga bisa disimpulkan jika 73,18\% variabel dijelaskan dalam 1 faktor yang terbentuk, yaitu faktor-faktor yang mempengaruhi keputusan pembelian.

Analisis selanjutnya adalah melihat faktor akhir sebelumrotasiyang telahterbentuk. Component Matrix $^{a}$

Dari hasil analisis bisa dilihat bahwa hanya ada 1 component faktor dengan 5 variabel di dalamnya yang meliputi harga dengan nilai loading faktor sebesar 0,897 , sosial dengan nilai loading faktor sebesar 0,894, psikologis 0,890, distribusi dengan nilai loading faktor sebesar 0,802, dan pribadi dengan dengan nilai loading faktor sebesar 0,786. Selain itu, keseluruhan variabel diatas nilainya telah lebih dari 0,5 sehingga component faktor akhir sebelum rotasi tersebut dapat dikatakan tepat untuk merangkum ke-5 variabel yang ada.

Oleh karena dalam faktor akhir sebelum rotasi hanya didapat 1 component, maka analisis yang terakhir yaitu rotasi faktor tidak dapat dilakukan. Rotasi faktor hanya bisa dilakukan jika hasil analisis awal menghasilkan setidaknya 2 conponent.

Dari hasil proses analisis faktor yang telah dilakukan bisa simpulkan bahwa faktor Harga, Sosial, Psikologis, Distribusi, dan Pribadi merupakan faktor-faktor yang membentuk keputusan pembelian minyak goreng Bimoli. Sedangkan faktor Produk, Promosi, dan Budaya bukan merupakan faktor yang membentuk keputusan pembelian.=

\section{1) Faktor Harga}

Harga memiliki peranan yang sangat penting dalam mempengaruhi keputusan konsumen dalam membeli produk, sehingga sangat menentukan keberhasilan pemasaran suatu produk. Definisi harga menurut Kotler dan Armstrong (2001:339) harga adalah jumlah uang yang dibebankan untuk sebuah produk atau jasa. Lebih luas lagi harga adalah jumlah nilai yang konsumen pertukarkan untuk mendapatkan manfaat dari memiliki atau menggunakan produk atau jasa. Jika dilihat dari tabel harga mempunyai nilai loading factor sebesar 0,897 dimana nilai ini lebih besar dari 0,5 sebagai pembentuk faktor-faktor keputusan pembelian minyak goreng Bimoli. Harga sebuah produk atau jasa merupakan faktor penentu dalam permintaan pasar. Harga merupakan hal yang sangat penting yang diperhatikan oleh konsumen dalam membeli produk atau jasa. Jika konsumen merasa cocok 
dengan harga yang ditawarkan, maka mereka akan cenderung melakukan pembelian ulang untuk produk yang sama.

\section{2) Faktor Sosial}

Keputusan pembelian minyak goreng Bimoli oleh konsumen juga di pengaruhi oleh sosial konsumen itu sendiri. Kotler (2005:206) dalam bukunya menuliskan bahwa di dalam sosialseorang konsumen terdapat kelompok acuan, keluarga, serta peran dan status yang baik secara langsung maupun tidak langsung berpengaruh terhadap keputusan konsumen dalam membentuk keputusan pembelian. Dari tabel bisa dilihat nilai loading factor sosial sebagai pembentuk faktor-faktor keputusan pembelian minyak goreng bimoli adalah sebesar 0,894. Melihat dari objek penelitian ini bisa disimpulkan bahwa kelompok acuan yang terdiri dari rekan kerja, teman dekat, dan rekan komunitas merupakan kelompok refensi yang dapat mempengaruhi konsumen dalam membeli minyak goreng Bimoli. Selain itu keluarga merupakan orang terdekat konsumen dalam kaitannya membeli minyak goreng Bimoli, sehingga konsumen membeli minyak goreng Bimoli karena ada keluarga yang membeli dan menggunakan minyak goreng yang sama.

\section{3) Faktor Psikologis}

Psikologis menjadi bagian penting dalam pembelian minyak goreng Bimoli, menurut Philip Kotler (2005:215) dalam membeli sebuah produk seorang konsumen di dasari oleh beberapa hal yang diantaranya, motivasi, persepsi, pembelajaran, dan sikap. Dari tabel bisa di lihat psikologis memiliki nilai loading factor sebesar 0,890 sebagai pembentuk faktor-fakktor keputusan pembelian minyak goreng Bimoli oleh konsumen. Hal ini menunjukkan bahwa dalam membeli minyak goreng Bimoli seorang konsumen mempunyai alasan yang berbeda-beda. Sehingga kondisi psikologis seorang konsumen bisa menjadi pemicu dalam membeli sebuah produk.

\section{4) Distribusi}

Distribusi berperan dalam pengalokasian barang atau jasa agar mudah dijangkau oleh konsumen. Dimana distribusi itu sendiri terdiri dari Saluran Distribusi dan Distribusi Fisik. Pengertian Distribusi menurut Kotler dan Amstrong dalam bukunya Principle Of Marketing (2000 :73), adalah :“Aktifitas Perusahaan agar produk / jasa mudahdidapatkan oleh konsumen sasaranya". Dari tabel bisa di lihat nilai loading

factor distribusi sebagai pembentuk faktor-faktor keputusan pembelian minyak goreng Bimoli adalah sebesar 0,802. Berpengaruhnya distribusi terhadap keputusan pembelian minyak goreng Bimoli adalah karena distibusi merupakan proses menyampaikan produk minyak goreng Bimoli dari produsen ke konsumen. Dalam hal ini peranan saluran pemasaran khususnya saluran distribusi sangat menentukan untuk dapat memasarkan produk minyak goreng Bimoli sampai ketangan konsumen. Pendistribusian ini juga meliputi ketersediaan produk minyak goreng Bimoli saat di butuhkan oleh konsumen. Ketersediaan produk minyak goreng Bimoli akan memudahkan konsumen yang akan melakukan pembelian minyak goreng ini.

5) Faktor Pribadi

Pribadi secara internal berpengaruh terhadap proses keputusan pembelian yang dilakukan oleh konsumen dalam membeli minyak goreng Bimoli. Dari tabel bisa di lihat nilai loading factor dari pribadi sebagai pembentuk faktorfaktor keputusan pembelian adalah sebesar 0,786. Kotler (2005:210), menjelaskan banyak hal yang terdapat pada pribadi seorang konsumen dalam pengaruhnya ketika membentuk keputusan pembelian, yang diantaranya adalah usia, pekerjaan, keadaan ekonomi, dan gaya hidup. Usia tidak menghalangi konsumen minyak goreng Bimoli untuk membeli minyak goreng ini, perkerjaan serta keadaan ekonomi mereka juga mendukung mereka untuk membeli dan menggunakan minyak goreng Bimoli, selain itu gaya hidup sehat dalam menggunakan minyak goreng kemasan bermerek yang lebih terjamin kebersihannya juga membuat konsumen akhirnya membeli minyak goreng Bimoli.

\section{KESIMPULAN}

1) Berdasarkan hasil penelitian mayoritas pembeli minyak goreng Bimoli adalah konsumen yang berusia antara 30-40 tahun. Latar belakang pendidikan akhir konsumen adalah SMA/SMK. Serta pendapatan dan pengeluaran antara 2.000.000- 3.000.000 per-bulan.

2) Alasan membeli minyak goreng Bimoli adalah karena harganya yang terjangkau. Televisi menjadi sumber informasi utama konsumen. Fokus perhatian konsumen saat membeli minyak goreng Bimoli adalah harganya. Selain itu kemudahan dalam memperoleh minyak goreng Bimoli membuat konsumen melakukan pembelian minyak goreng ini, karena mayoritas konsumen merencanakan pembelian sebelum melakukan pembelian. Konsumen juga merasa puas menggunakan minyak goreng Bimoli. 3) Berdasarkan hasil wawancara terdapat beberapa alasan ibu rumah tangga Desa Kebonagung Kecamatan Purworejo Kota Pasuruan dalam membeli minyak goreng 
Bimoli, yang diantaranya adalah merek, kualitas produk, harga, ketersediaan produk, keluarga, serta persepsi dan motivasi.

4) Dari hasil analisis faktor terdapat 5 faktor yang dipertimbangkan dalam keputusan pembelian minyak goreng Bimoli pada ibu rumah tangga Desa Kebonagung Kecamatan Purworejo Kota Pasuruan, yang antara lain : harga, sosial, psikologis, distribusi, dan pribadi

\section{SARAN}

a. Harga merupakan salah satu faktor yang dipertimbangkan dalam membeli minyak goreng Bimoli. Untuk itu perusahaan bisa melakukan promosi penjualan secara berkala dengan memberi potongan harga terhadap minyak goreng Bimoli. Mengingat promosi bukanlah faktor yang dipertimbangkan konsumen dalam membeli minyak goreng Bimoli. Maka dengan mengadakan promosi penjualan secara berkala konsumen akan lebih terdorong lagi untuk membeli minyak goreng Bimoli sehingga konsumen akan merasa puas dan diuntungkan dengan membeli minyak goreng Bimoli.

b. Ketersediaan minyak goreng Bimoli ditempat-tempat konsumen terbiasa membeli kebutuhan pokok menjadi salah satu alasan konsumen membeli minyak goreng Bimoli. Mengingat minyak goreng adalah kebutuhan pokok, perusahaan harus membuat saluran distribusi yang memudahkan konsumen untuk mendapatkan minyak goreng Bimoli.

c. Dari hasil penelitian juga diketahui bahwa perilaku konsumen yang berkaitan dengan perilaku konsumen yang berkaitan dengan pribadi, sosial, dan psikologis menjadi pertimbangan konsumen dalam membeli minyak goreng Bimoli. Yang perlu diperhatikan perusahaan berkaitan dengan hal ini adalah bahwa faktor internal pribadi seorang konsumen yang berhubungan dengan usia, kondisi ekonomi, serta gaya hidup membuat konsumen mempertimbangkan produk seperti apa yang akan dibeli. Selain itu faktor sosial konsumen juga diperhatikan, mengingat keluarga dan kelompok referensi seperti teman kerja, teman dekat, teman sekomunitas merupakan orangg terdekat yang bias mengarahkan seorang konsumen untuk membeli sebuah produk. Hal ini bisa dimanfaatkan oleh perusahaan untuk lebih bisa mempromosikan minyak goreng Bimoli, misalnya dengan mengadakan acara memasak bersama dengan teman sekomunitas dengan menggunakan minyak goreng Bimoli. Dengan begitu konsumen dalam komunitas tersebut akan lebih loyal terhadap produk minyak goreng Bimoli. Dan mereka yang ada dalam komunitas tersebut bisa mengarahkan teman-teman dalam jaringan komunitas mereka untuk membeli minyak goreng Bimoli. Selain itu kondisi psikologis seorang konsumen juga seharusnya menjadi perhatian, karena kondisi ini berkaitan dengan persepsi dan motivasi seorang konsumen dalam membeli sebuah produk. Perusahaan seharusnya bisa terus menanamkan persepsi yang baik tentang minyak goreng Bimoli kepada konsumen, sehingga konsumen termotivasi untuk membeli minyak goreng Bimoli

\section{DAFTAR PUSTAKA}

1. _______ Bimoli. 2 September 2016.

http://www.bimoli.com/tentangbimoli/produk-kami

2. _. Desa/Kelurahan Menurut Status Pemerintahan dan Jumlah RT/RW, 2014. 13

Maret 2016.

https://pasuruankota.bps.go.id/linkTabel Statis/view/id/1170

3. Sejarah. 2011.2 September 2016. http://www.simp.co.id/AboutSIMP/ History.aspx

4. . Daftar Harga Minyak Goreng

Terbaru September 2016. 2 September 2016. Seputar harga terkini.com/daftar-hargaminyak-goreng-terbaru-september2015/.

5. Tiga Merek Raih

Penghargaan IBBA 2011. 13 Maret

2016.https://www.tempo.co/read/news/2011 /07/26/140348310/tiga-merk-raihpenghargaan-ibba2011.

6._______________anian.13 Maret2016. https://belajar.kemdikbud.go.id/Sumber Belajar/tampilajar.php?ver=11\&idmat eri=182\&mnu=Materi2\&kl=7.

7. . Top Brand Dalam Pasar

Komodity Bermerek. 13 Maret 2016.

http://www.topbrand-award.com/article/topbrand-dalam-pasar-komoditi-bermerek.html.

8. ___ Top Brand Index 2016 Fase

1 Situs. 2 September2016. www.topbrandaward.com/top-brand-survey/surveyresult/top_brand_index_2016_fase_1.

9. Arikunto, Suharsini. 2002.Prosedur Suatu

Penelitian : Pendekatan Praktek. Edisi

Revisi Kelima. Jakarta : Rineka Cipta

10. Arikunto, Suharsini. 2006. Hipotesis 
Penelitian. Bandung : PT Rosda

11. Dwinada, Frizky. 2012. Analisis Faktor-

Faktor Keputusan Pembelian Minyak

Goreng Kemasan Merek Bimoli (Studi

Kasus : Rumah Tangga di Kota Bogor).

Bogor : Institut Pertanian Bogor

12. Fure, Hendra. 2013. Lokasi, keberagaman produk, harga, dan kualitas pelayanan pengaruhnya terhadap minat beli pada pasar tradisional Bersehati Calaca.ISSN 2303-1174

13. Hadi, Sutrisno. 2000. Metodologi Penelitian. Yogyakarta: Andi

14. Husein Umar, 2005. Metode Penelitian. Jakarta : Salemba Empat

15. Jayakusumah, Herdi. 2011. Analisis FaktorFaktor Yang Mempengaruhi Konsumen Dalam Keputusan Pembelian Teh Celup Sariwangi (Studi Kasus Pada masyarakat Kota Bekasi). Jakarta : Universitas Is lam negeri Syarif Hidayatullah

16. Kotler, Philip dan Amstrong, Gary. (2000). Prinsip-prinsip Pemasaran (Principles of Marketing), Edisi Bahasa Indonesia, Jilid I. Jakarta: Penerbit Erlangga.

17. Kotler, Philip dan Amstrong, Gary. 2001. Prinsip-prinsip pemasaran, Edisi keduabelas, Jilid 1. Jakarta: Erlangga.

18. Kotler, Philip dan Amstrong, Gary. 2004. Prinsip-prinsip Marketing, Edisi Ketujuh. Jakarta: Penerbit Salemba Empat.

19. Kotler, Philip. 2005. Manajemen Pemasaran. Jakarta : PT Intan Sejati Klaten

20. Kotler, Philip. 2007. Manajemen Pemasaran. Jakarta : PT Intan Sejati Klaten

21. Kotler, Philip dan Keller, Kevin Lane. 2009.

Manajemen Pemasaran. Jilid I. Edisi ke 13. Jakarta: Erlangga

22. Kotler, Philip dan Amstrong, Gary. 2012. Prinsip-prinsipPemasaran. Edisi. 13. Jilid 1. Jakarta: Erlangga

23. Maharani, Arina. 2014. Faktor-Faktor Yang Mempengaruhi Keputusan Pembelian Di Warung Bakso Sari Gurih Pak Ratno. Yogyakarta : Universitas Negeri Yogyakarta

24. Margono. 2004. Metodologi Penelitian Pendidikan. Jakarta: Rineka Cipta Nasution. 2003. Metode Research. Jakarta : PT Bumi Aksara

25. Prasetya, Frendy. 2011. Analisis Pengaruh Diferensiasi, Promosi Dan Positioning
Terhadap Keputusan Pembelian. Semarang :

Universitas Diponegoro

26. Riduwan, 2005. Metode dan Teknik

Menyusun Tesis, Cetakan Ketiga. Bandung. :

Alfabeta

27. Sanusi, Anwar. 2011. Metode Penelitian

Bis nis.Jakarta : Salemba Empat.

28. Sarwono, Jonathan. 2006. Metode Penelitian

Kuantitatifdan Kualitatif. Yogyakarta :

Graha Ilmu

29. Simamora, Henry. 2000. Manajemen pemasaran international jilid II Cet. 1. Jakarta: Salemba Empat

30. Simamora, Henry. 2004. Manajemen Sumber Daya Manusia. Yogyakarta : STIE

31. Singarimbun, Masri, dan Sofian Efendi. 2006.

Metode Penelitian Survey. Jakarta : LP3ES

32. Sugiyono.(2001). Metode Penilaian.

Bandung: Alfabeta

33. Sugiyono. 2009. Metode Penelitian Administrasi Dilengkapi Metode R \& D. Bandung : Alfabeta

34. Sugiyono. 2011. Metode Penelitian Kuantitatif, kualitatifdan $R \&$ D. Bandung : Alfabeta

35. Suwarman, Ujang. 2002. Perilaku Konsumen. Bogor: Ghalia Indonesia.

36. Tjiptono, Fandy. 2008. Strategi Pemasaran, Edisi Ketiga. Yogyakarta : Andi 